Anthi Dipla

Hellenic Open University, Open University of Cyprus

\title{
AN "IDYLLIC" WORLD \\ AGAINST WAR ATROCITIES; IMAGES OF ELEGANCE, ESCAPISM AND LIBERATION IN THE MIDST OF THE PELOPONNESIAN WAR
}

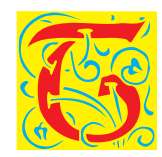

his presentation proposes to explore the impact of the Peloponnesian War -a bloody and disastrous civil war between Athenians and the Delian League and Spartans and the Peloponnesian League, 431-404 $\mathrm{BC}^{1}$ - on the society of Late Classical Athens, as reflected on the images of women in the popular art medium of vase-painting. These years saw the dramatic decline of citizen population in both Athens and Sparta. Losses due to war and plague in Athens have been estimated, according to Thucydides, to the range of about one third of the original male, citizen population. ${ }^{2}$

The last part of the $5^{\text {th }} \mathrm{c}$. BC was the age of some of the greatest achievements of Classical poetry, philosophy and science. The great Aristophanes, Sophocles and Euripides were active, whereas the less known -but equally popular at the time- tragedian Agathon was proclaimed a "master of the flowery phrase", while he apparently led a life of vanity and grace. ${ }^{3}$ Meanwhile Socrates was conversing with the youth of Athens, in the Agora and at

1 C. Rolley, La sculpture grecque Vol. 2. La période classique, Paris, 1999, 23-24.

2 J. H. Oakley, "Children in Athenian Funerary Art During the Peloponnesian War," in: O. Palagia (ed.), Art in Athens During the Peloponnesian War, Cambridge 2009, 207208, 229-230. G. L. Ham, "The Choes and Anthesteria Reconsidered: Male Maturation Rites and the Peloponnesian Wars," in: M. W. Padilla (ed.), Rites of Passage in Ancient Greece: Literature, Religion, Society, London/Toronto 1999, 209-210.

3 P. Lévèque, Agathon, Paris, 1955, chapters 2 and 3. 
various private banquets, and the scientific study of medicine by the authors of the Hippocratic treatises coexisted with prevalent popular superstitions, the practice of magic and an interest in exotic cults. ${ }^{4}$

\section{Trends in subject matter and iconography of contemporary Athenian vase-painting}

During the war greater emphasis was placed on women themes. Moreover, a trend may be traced in the last part of the fifth century to mix the iconographies of the respectable (brides) with the disreputable (hetaerae). Throughout the Classical times, and especially in this period, hetaerae may appear in activities of the industrious housewife, such as spinning (Figure 1). Conversely, in certain cases solemn wives (?) are depicted being accosted and courted like hetaerae (high-class prostitutes). For example, brides appear in scenes of gift exchange, normally reserved for accosted hetaerae, or in sensual bathing, such as in "voyeuristic" views of brothels. ${ }^{5}$

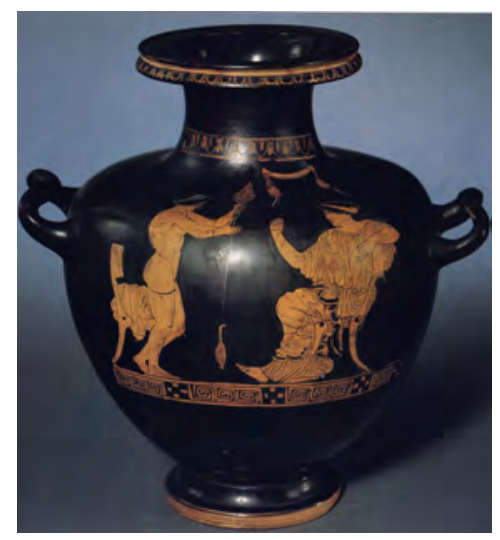

Figure 1. Red-figure Hydria, Copenhagen, National Museum of Denmark, inv. no. CHR.VIII.520, Washing Painter, 440-430 BC.

Naked hetaera spinning in front of the brothel madam

Source: Photo reprinted from E.D. Reeder (ed.), Pandora; Women in Classical Greece. (Baltimore 1995), Cat. no. 50.

${ }^{4}$ L. Burn, The Meidias Painter, Oxford, 1987, 13-14.

5 G. Ferrari, Figures of Speech; Men and maidens in Ancient Greece, Chicago/London, 2002, 12-17. See also: V. Räuchle, Die Mütter Athens und ihre Kinder; Velhaltens-und Gefühlsideale in klassischer Zeit, Berlin/London 2017, 142-147. 
Around 440 Eros and from about 430 Aphrodite and her retinue are meaningfully shown often participating in the bridal preparation, suggesting the strong appeal of bridal adornment. By the so-called Rich Style (420-400 BC) Aphrodite and Eros have assumed a prevalent role in the bridal adornment (Figure 2). The gynaikeion, where the festive adornment of the bride (as well as the daily female toilette) takes place, turns into a new, idyllic world. By the Late Classical period the public aspect of the Athenian wedding ritual is downplayed on vases and the private aspect is emphasized, especially the bridal adornment. Wedding gradually becomes a female theme, associated with vase shapes of the female toilette, such as cosmetic boxes or perfume bottles, while earlier they decorated mostly ritual vases or tableware. ${ }^{6}$

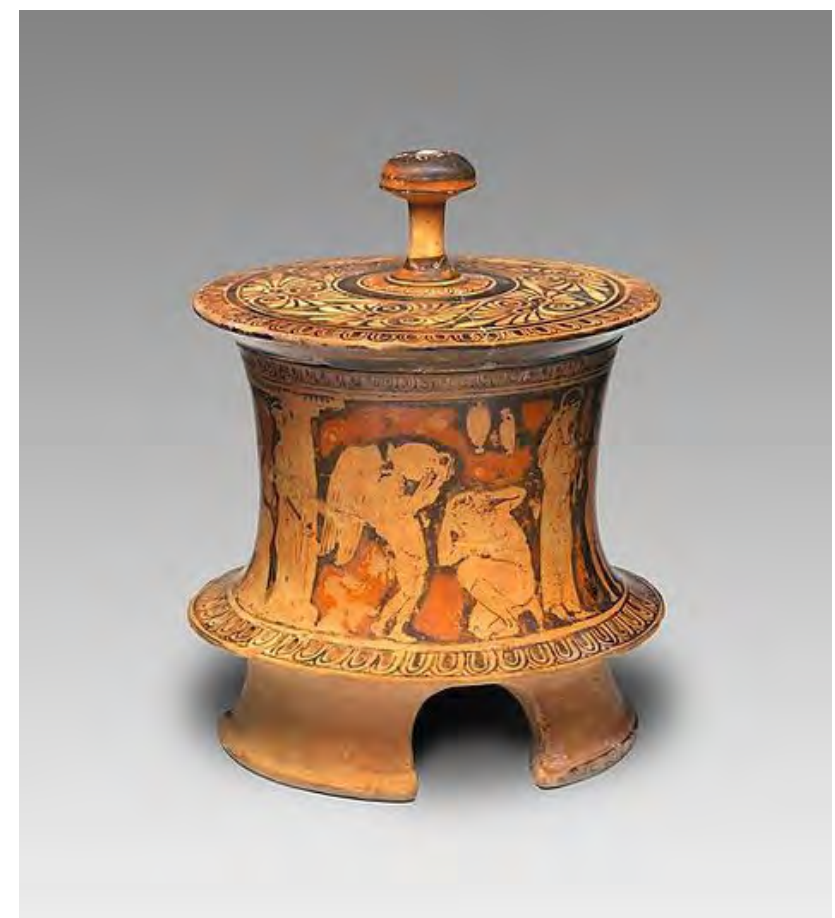

Figure 2. Red-figure pyxis, New York, Metropolitan Museum of Art, 1972.118.148, ca. 420. Eros pours water for a naked bride to wash her hair. The first in a series of vignettes from the bridal preparation Source: Photo reprinted from the Met Homepage.

${ }^{6}$ A. Dipla, "Eros the Mediator; Persuasion and Seduction in Pursuit and Courting Scenes," Mediterranean Archaeology and Archaeometry 6.2, December, 2006, 28-30. 
In scenes of heterosexual courting women are frequently shown being lured by either material gifts or a mediating Eros, as if being persuaded. What could their identity be? Are they meant to be hetaerae (foreigners, metics) or respectable Athenian wives and daughters of Athenian citizens (astai)? Classically all these scenes are identified as visits to a brothel, based on internal evidence (offer of money) as well as external evidence (the supposed seclusion of Athenian astai). This view, however, has recently been disputed Regardless of the exact (or intended ambivalent) identity of these women, the essential message remains that women may be seductive, as well as susceptible to seduction themselves. ${ }^{7}$

\section{"Androgynous" women in Aristophanes and the possibility of female emancipation}

The trend of blurred identities of wives and prostitutes and acknowledgement of female seductive power, or even desire, has been explained from the depopulation of men, owing to war losses and the consequent possible emancipation of women who took charge of the oikos and broke free from the constrictions of the social seclusion prevalent in the High Classical period. "Androgynous" women in the Aristophanic comedy could be pointing in the same direction. It has been proposed that the masculinity of actors playing women intruded both text and performance of the Aristophanic comedies. This has been explained as revealing the illusion of gender disguise, or stressing the metatheatricality of Attic comedy, appealing to an essentially male audience. Or even as offering a distorted view of gender roles (namely, reversal), winking a reassuring eye at the male audience and aiming to reinforce cultural images and assumptions. However, it cannot be excluded that this androgynous identity of Aristophanic female characters manifests rather a newly acquired emancipation of women who enjoy a public presence and voice, as well as the manipulation of their power of seduction (as illustrated, for example, in Thesmophoriazusae, Ecclesiazusae, Lysistrata, or Peace). ${ }^{8}$

7 A. Dipla, D. Paleothodoros, "Selected for the Dead; Erotic Themes on Vases from Attic Cemeteries," in: I-M. Back-Danielsson, F. Fahlander and Y. Sjöstrand (eds), Encountering Imagery; Materialities, Perceptions, Relations, Stockholm, 2012, 221-222.

${ }^{8}$ L. K. Taaffe, Aristophanes and Women, London/New York, 1993, chapters 3 and

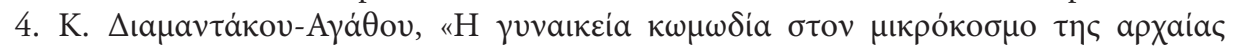


However, the evidence from the sources is admittedly contradicting and should be handled with caution. We can trace a profound ambivalence about women and their sexuality; meanwhile we cannot be sure either how closely social reality followed the social ideal. ${ }^{9}$

\section{Case study: The Meidias Painter and his associates}

In the work of the Meidias Painter and his group (artists painting in the style or manner of the Meidias Painter), active roughly in the years of the Peloponnesian war, ${ }^{10}$ divine, heroic or mortal women with voluptuous bodies, in elegant clothing, and assuming graceful poses and gestures, ${ }^{11}$ are depicted seduced by Erotes (ephebe love gods), or even abducted by their suitors, adorned to be wedded, cuddling with lovers, or just idling on their own, in an idyllic natural setting (a garden?) (Figures 3,4). ${ }^{12}$ The same ambience is portrayed by Agathon in a panegyric speech, cited in Plato's Symposium: the most blissful of all gods, Eros is young, delicate, graceful and shapely. He dwells in soft souls, where "he fathers delicacy, voluptuousness, all the graces, longing and desire". ${ }^{13}$

Mythological and generic scenes on Meidian vases are dominated by women, often in a nuptial context, characterized by great ambiguity. Several questions arise: to begin with, are these women mortal or divine? What are their gardens? Xenophon stresses that a woman's nature is made for indoor works and matters. Is this merely a fantasy of entering Aphrodite's meadows of love? Or an expression of nostalgia for the Attic countryside from which the Athenians were cut off during the war? ${ }^{14} \mathrm{Or}$ also partly a reality of breaking free to some extent from their presumed seclusion?

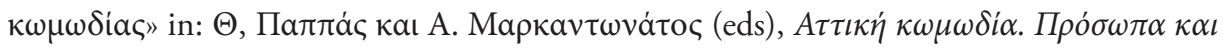

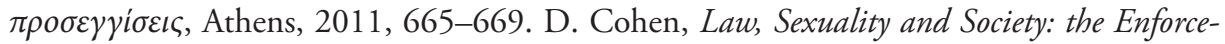
ment of Morals in Classical Athens, Cambridge/New York 1991, 164-166.

9 Ferrari, Figures of Speech, chapter 3.

10 Burn, Meidias P., 1-8.

11 G. Nicole, Meidias et le style fleuri dans la céramique attique, Geneva, 1907, 105-112.

12 Burn, Meidias P., passim, esp., chapters 3 and 7. M. Robertson, The Art of Vase-painting in Classical Athens, Cambridge, 1996, 237-242.

13 Plato, Symposium, 194e-198a. Burn, Meidias P., 14.

14 Burn, Meidias P., 84-85. 

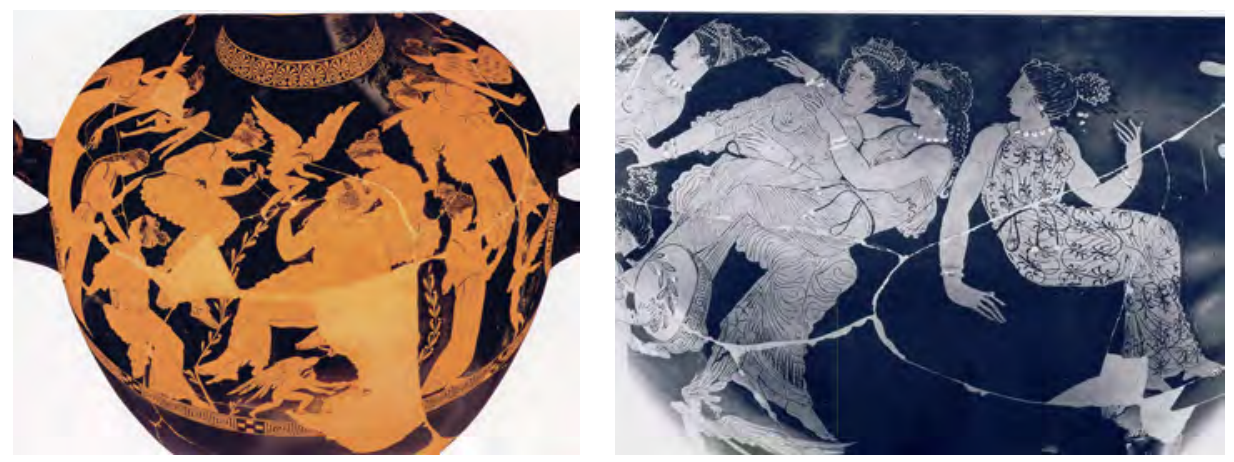

Figure 3a-b. Red-figure, hydria, Florence Archaeological Museum, inv. no. 81948, Meidias Painter, ca. 415.

Adonis rests leaning against Aphrodite's knees in a garden, surrounded by the goddess' retinue, among whom four Erotes

Source: Photos reprinted from N. Stambolidis (ed.), Eros; from Hesiod's Theogony to Late Antiquity (Athens 2009), Cat. no. 133. and L. Burn, The Meidias Painter (Oxford 1987), pl. 23b.
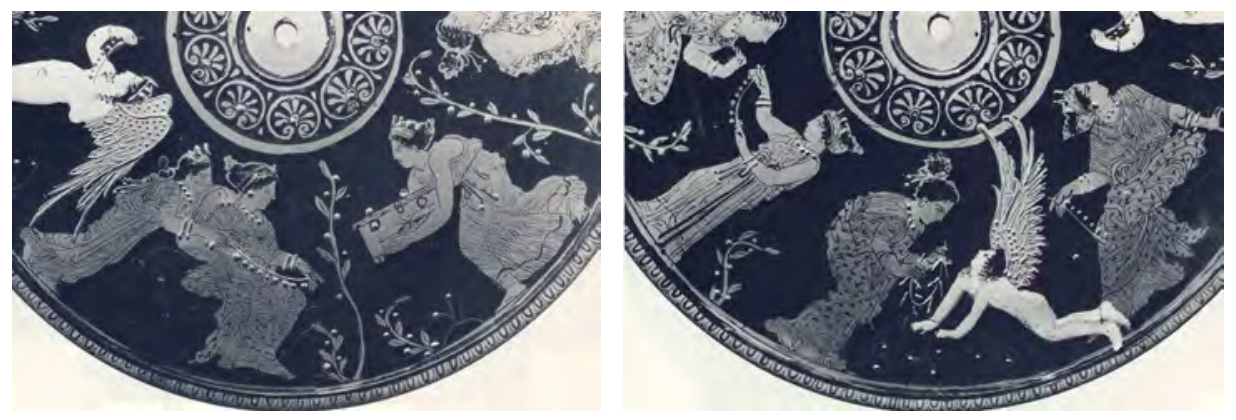

Figure 4a-b. Red-figure pyxis, Oxford G.302 (V. 551), Meidias Painter, late $5^{\text {th }}$ c. BC. Graceful women in elegant, transparent clothes adorn themselves in a garden (?), suggested by the rocks and shrubs with berries. Erotes attend or seduce them Source: Photos reprinted from L. Burn, The Meidias Painter (Oxford 1987), pl. 49a-b.

\section{Women's presumed separation and the segregation of house spaces}

In recent studies of the spatial and socio-cultural organization of Classical and Hellenistic houses, the evaluation of architectural layout and find assemblages, along with cross-cultural, ethnographic comparisons, seem to suggest 
that there was no strict spatial separation of household members, by gender, age or status. Most rooms were probably multifunctional and maybe only the andron can be proven to be a gendered space, restricted to male use, but again possibly not at all times. The participants, rather than the activities themselves, could therefore have determined where the activities were located, so as to serve, for example, the necessity to control undesired contact of women with the outer world. ${ }^{15}$ The usual type of houses with one or two courtyards may have been designed not to provide separate male and female quarters within the house, but to create a specific male area, the andron, in which to receive male visitors from outside the family without risking casual contact with the women of the house. Consequently the term gynaikeion may have denoted the house as a whole, apart from the andron. ${ }^{16}$ Spaces with such distinctive features can only be detected, however, in excavated houses from the later fifth century. ${ }^{17}$

Moreover, seclusion does not always involve separation, and separation does not necessarily imply seclusion, as anthropological studies have shown. ${ }^{18}$ Apart from the archaeological record not supporting the assumption of confinement and separation within the Greek household, the idea of overall seclusion of women from public life in Classical times has also been questioned. Though numerous literary sources attest to it, there are several limitations and biases built into them, obscuring the great underlying variability of the social role of women in different social strata or city-states across Greece. Hence they should be regarded as representing a male idealized viewpoint about what upper-class Athenian women should aspire to, rather than they necessarily practiced. ${ }^{19}$ Other than that, women participated in a complex network of activities with an autonomy of its own. This network, functioning within the private sphere of the oikoi, the extended family, the neighbourhood, and on occasions such

15 M. Trümper, "Space and Social Relationships in the Greek Oikos of the Classical and Hellenistic Periods," in: B. Rawson (ed.), A Companion to Families in the Greek and Roman Worlds, Malden, MA 2011, 32-52.

${ }^{16}$ L. Nevett, "Separation or Seclusion? Towards an Archaeological Approach to Investigating Women in the Greek Household in the Fifth to Third Centuries BC.," in: M. P. Pearson and C. Richards (eds), Architecture and Order; Approaches to Social Space, London/New York, 1994, 98-112.

17 L. C. Nevett, Domestic Space in Classical Antiquity, Cambridge, 2010, 43-50.

18 D. J. Cohen, Law, Sexuality and Society, chapter 6.

19 L. C. Nevett, "Separation or Seclusion? Towards an Archaeological Approach to Investigating Women in the Greek Household in the Fifth to Third Centuries BC.”..., 98-100. S. Lewis, The Athenian Woman: An Iconographic Handbook, London, 2002, 138. 
as birth, marriage, funeral and exclusive religious festivals, ran parallel to the male-dominated, public one of state politics and economy. Within their own sphere women may have enjoyed independence, freedom and self-assertion. ${ }^{20}$

\section{The Meidian style against the background of similar trends in sculpture and major painting}

The idyllic ambience in the aforementioned vase scenes is complimented by the "Meidian" luxurious drawing, the elaborate, even gilded details. Dress either clings to the body, barely concealing it, or swirls away, creating calligraphic folds. This florid style displays a sensuous, flirtatious, rather than a menacing mood..$^{21}$ A comparable trend may be detected in contemporary sculpture and, in a sense, in major painting, even a little before the outbreak of the war.

Similar graceful poses of especially female figures, as well as the elaborate dress, either clinging to the body stressing sensuousness, or creating swirling flourishes and a dramatic, can be traced in the so-called Rich Style, as illustrated for example in the Parthenon pedimental sculptures, in an early version, or later on in the sculptures of the parapet surrounding the temple of Athena Nike on the Acropolis (Figure 5).22

In contemporary major painting, which exactly in this period began to influence less and less vase-painting, artists experiment with creating the illusion of volume either through the skillful drawing of outline, a trend associated with Parrhasi's, or through the manipulation of light and shadow, linked with Apollodoros, known as skiagraphos, the shadow-maker, who introduced an innovative mixture of light and dark tones and color gradations to produce some sort of perspective. Zeuxis was Apollodoros' pupil, who may furthermore have introduced genre subjects into painting. Both Parrhasios and Zeuxis led a life of sybaritic luxury and amassed great wealth out of their art, creating masterpieces of outstanding illusionism. ${ }^{23}$ or those able to afford them and willing to indulge in a world of fantasy and deceptive visual surroundings. Pliny the Elder

20 D. J. Cohen, Law, Sexuality and Society, 146-166.

${ }^{21}$ J. Boardman, Athenian Red Figure Vases; The Classical Period, a Handbook, London, 1995, 144-147. J. G. Pedley, Greek Art and Archaeology, London, 2002, 283.

22 See for example: C. Rolley, Sculpture classique, 112-115, 123-125.

23 Pliny, Natural History, 35. 36. 65- 


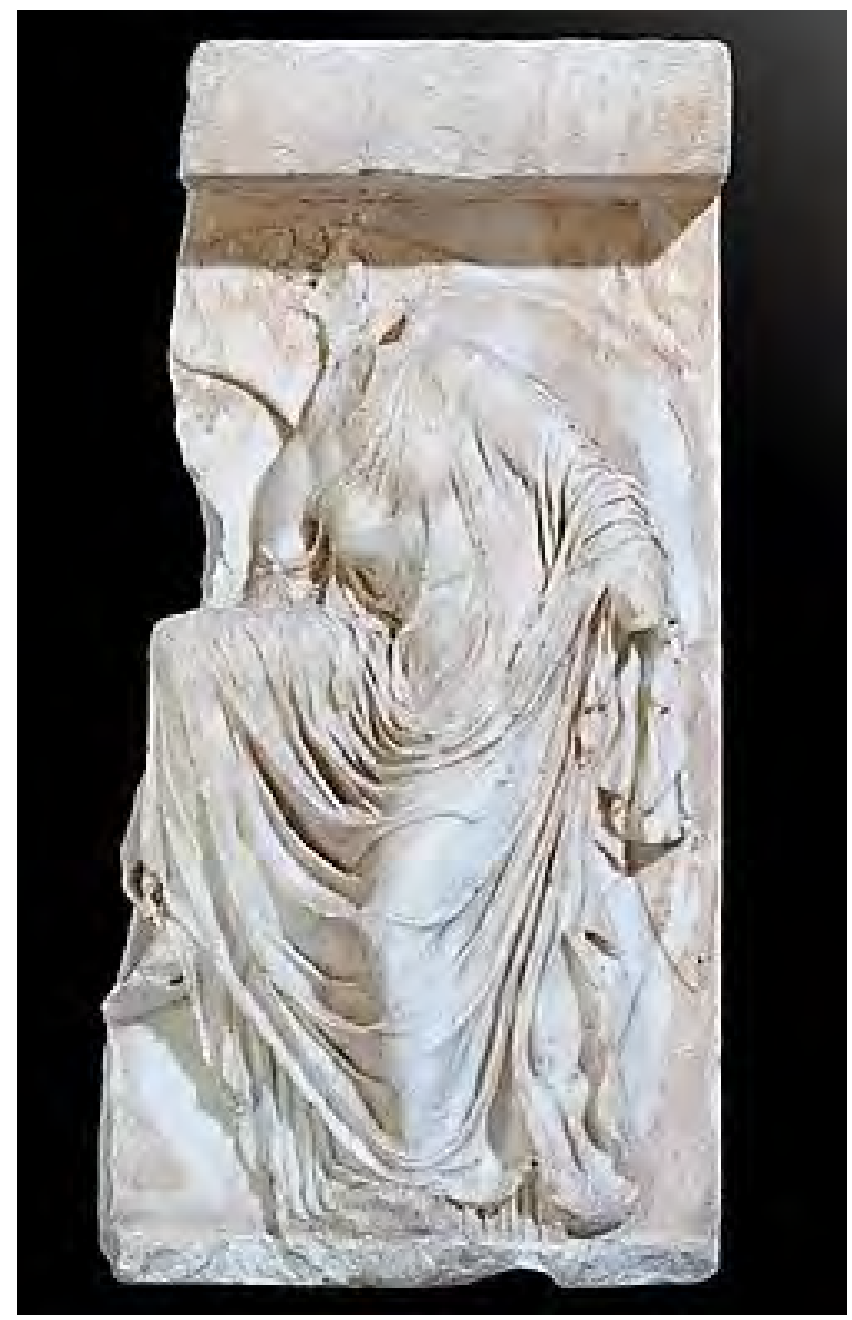

Figure 5. Parapet of the Temple of Athena Nike, Athens Acropolis, ca. 410 BC. Nike untying her sandal

Source: Photo reprinted from the Acropolis Museum Homepage.

recounts an anecdote about the contest of the two masters in creating perfect imitations of reality. A lingering naturalistic idealism, nevertheless, called for an eclectic depiction of the most beautiful forms, so as to create a perfection that may not exist in nature. ${ }^{24}$

24 S. Lydakis, Ancient Greek Painting and its Echoes in Later Art, Los Angeles, 2002, 120-125, 128-136. M. Robertson, The Art of Vase-painting in Classical Athens, Cambridge, $1996,237,253-254$. 


\section{Extravaganza vs wretchedness in contemporary Europe: the example of Greece}

An escapist tendency may be attested in European countries undergoing political and/or financial crisis, or even war, such as Greece. In the wake of a civil war, a military junta, political corruption and eventually heavy financial crisis, since Greece is currently under the vigilance of the International Monetary Fund, the European Commission EC and the European Central Bank ECB, while the sustainability of Greek debt still remains in question, Greek popular media, such as TV and magazines, the equivalent of ancient vases in some sense, have witnessed a boom in fashion and lifestyle reports and shows, around the glamorous lives of celebrities, as well as series depicting romantic stories set in luxurious or idyllic settings. On the other hand, recent war conflicts in Europe, such as in former Yugoslavia, or even in the Near East causing an influx of immigrants to Europe, especially Greece, have deprived many traditional families from their male head, so that previously secluded women may appear more emancipated and liberated within less than a generation.

The Meidias Painter, his associates and his contemporaries presumably catered for the Athenians' need to seek relief from the somber realities of their time, inscribed within a general shift in the Athenian society towards individualism, as the continuing war and the plague -of which Pericles himself perished- aggravated individual and family distress. ${ }^{25}$ Consequently artists engaged in a fantasy world of love adventures in a paradisiac environment, where the representation of the female body was characterized by an observable femininity, even voluptuousness, and sensuousness. A similar late- $5^{\text {th }}$ century ideal of male beauty called for a degree or effeminacy, youthfulness and extreme heterosexuality. ${ }^{26}$ Meanwhile, we can trace a sudden, distinctive interest in children in vase-painting and funerary sculpture of the time, as well as in

25 L. Kallet, "War, Plague, and Politics in Athens in the 420s," in: O. Palagia, Art During the War, 111-112.

${ }^{26}$ H. A. Shapiro, "Alcibiades. The Politics of Personal Style," in: O. Palagia, Art During the War, 236-263. 
literature. ${ }^{27}$ In particular, a short-lived, two-generation long fashion for small choes, miniature jugs presented to children aged three to four on the second day of a spring festival of Dionysus (also called Choes), with a conventionalized iconography of small children, mostly boys (Figure 6), has been linked to the ritual passage of children from infancy to early childhood, less vulnerable to death, celebrating the survival of sufficient (male, citizen) population, of crucial importance to the future of the city. Such images provided a "cultic response to a social crisis...", even if they did not act in the spirit of confrontation with these harsh realities, but of escapism, manifesting nostalgia for the carefreeness and joyfulness of early youth, as has also been suggested. ${ }^{28}$ Likewise, the marked acknowledgement of female sexuality, already traceable earlier in the $5^{\text {th }} \mathrm{c}$. BC and within the context of marriage, may merely have served the social demand for population renewal, glorifying motherhood and projecting a pronatalistic message. Conversely, it cannot be excluded that this sensual and romantic context resonates, at least to a certain extent, the sexual emancipation of women in the years of the Peloponnesian war, as a result of their greater social freedom that transcended the private sphere.

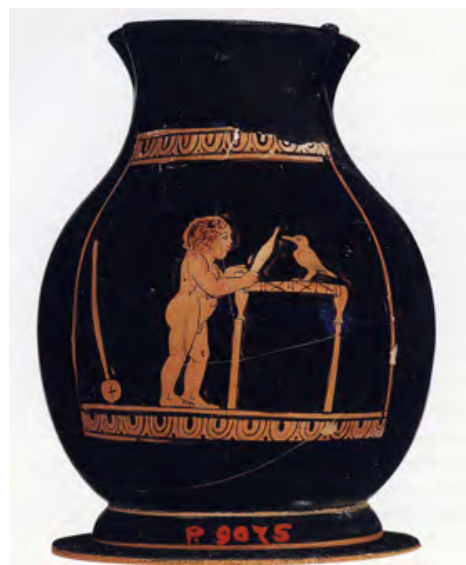

Figure 6. Red-figure chous, Boston, Museum of Fine Arts, acc. no. 01.8086, ca. 425-420.

Naked boy playing with his pet bird

Source: Photo reprinted from J. Neils and J.H. Oakley (eds), Coming of Age in Ancient Greece; Images of Childhood from the Classical Past (New Haven/London 2003), Cat. no. 91.

${ }^{27}$ J. H. Oakley, "Children in Funerary Art During the Peloponnesian War"..., especially, 226-231.

${ }^{28}$ G. L. Ham, "The Choes Reconsidered: Male Maturation Rites and the Peloponnesian Wars"..., 201-218. 